
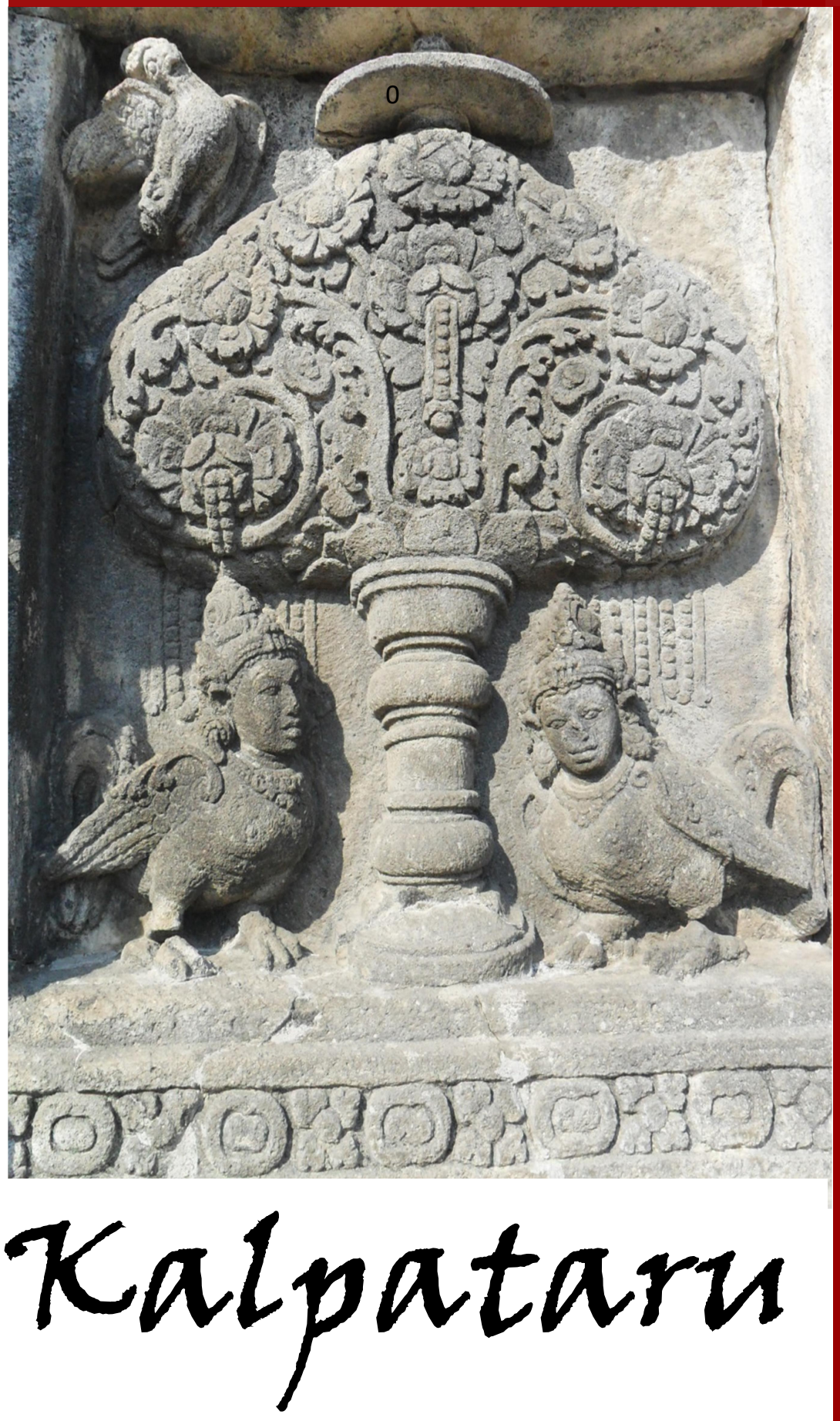

\author{
JURNAL SEJARAH DAN \\ PEMBELAJARAN SEJARAH
}

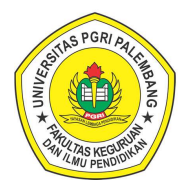

Program Studi Pendidikan Sejarah Jurusan Pendidikan IPS

Fakultas Keguruan dan IImu Pendidikan Universitas Persatuan Guru Republik Indonesia Palembang
Pengaruh Model Pembelajaran Student Facilitator and Explaining Terhadap Hasil Belajar Siswa Pada Mata Pelajaran Sejarah Kelas $X$ di SMA Negeri 3 Palembang

Sarinah, Nur Ahyani, Ahmad Zamhari

Pengaruh Model Pembelajaran Berbasis Masalah (PBM) Terhadap Hasil Belajar Siswa Pada Mata Pelajaran IPS Terpadu (Sejarah) Kelas VIII di SMP Negeri 2 Palembang

Neka Dapistri, Nur Ahyani, Ahmad Zamhari

Penerapan Media Pembelajaran Menggunakan Google Earth Dalam Materi Kondisi Masyarakat Indonesia Pada Masa Penjajahan Terhadap Hasil Belajar Siswa Pada Mata Pelajaran IPS Terpadu di SMP Quraniah Palembang

Tri Nur Ariani, Eva Dina Chairunisa, Ida Suryani

Perkembangan Sosial Budaya Suku Jawa di Desa Kapasan Tegalrejo BK $X$ Kecamatan Belitang Kabupaten Ogan Komering Ulu Timur Sebagai Sumber Pembelajaran Sejarah di SMA Muhammadiyah 2 Karang Tengah

Ratna Puspita Dewi, Sukardi, Mirza Fansyuri

Pengembangan E-Modul Pembelajaran Sejarah Tokoh-Tokoh Pembangunan

Susi Susanti, Eva Dina Chairunisa

Peran Pendidikan Sejarah Dalam Membentuk Karakter Bangsa

Sukardi, Jeki Sepriady

Sejarah Pengajaran Mantra Melayu di Tengah Perubahan Masyarakat Besemah Muhamad Idris, Eva Dina Chairunisa, Jeki Sepriady

Pengembangan Media Audio Visual Sejarah Kolonialisme Barat di Indonesia Materi Benteng Marlborough Bengkulu Hamza Kurniawan 


\section{Kalpataru}

Jurnal Sejarah dan Pembelajaran Sejarah

Volume 6, Nomor 2, Desember 2020

\section{Chief Editor}

Drs. Sukardi, M.Pd.

\section{Editor}

Dr. Muhamad Idris, M.Pd.

Eva Dina Chairunisa, M.Pd.

Jeki Sepriady, S.Pd.

\begin{tabular}{ll}
\multicolumn{2}{c}{ Reviewer } \\
Dr. Tahrun, M.Pd. & (Universitas PGRI Palembang) \\
Drs. Supriyanto, M.Hum. & (Universitas Sriwijaya Palembang) \\
Dra. Retno Purwati, M.Hum. & (Balai Arkeologi Sumatera Selatan) \\
Dr. Nor Huda Ali, M.Ag., M.A. & (Masyarakat Sejarawan Indonesia Sumsel) \\
Dr. Budi Agung Sudarman, S.S., M.Pd. & (Balai Bahasa Provinsi Sumatera Selatan) \\
Dr. Purmansyah, M.A. & (Universitas Muhammadiyah Palembang)
\end{tabular}

Alamat Redaksi

Program Studi Pendidikan Sejarah

Fakultas Keguruan dan IImu Pendidikan Universitas PGRI Palembang

Telp. 0711-510043

Email: jurnalkalpatarusejarah@gmail.com

Website: https://jurnal.univpgri-palembang.ac.id/index.php/Kalpa 


\section{Kalpataru}

JURNAL SEJARAH DAN

PEMBELAJARAN SEJARAH

Terbit dua kali setahun pada Juli dan Desember

Diterbitkan oleh:

Program Studi Pendidikan Sejarah

Jurusan Pendidikan IPS

Fakultas Keguruan

dan IImu Pendidikan

Universitas PGRI Palembang

\section{Gambar Cover:}

Pohon Kalpataru

Candi Prambanan

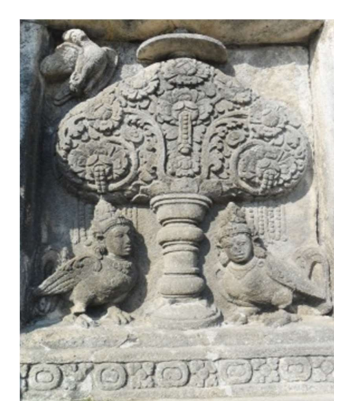

Koleksi: Muhamad Idris 


\section{DAFTAR ISI}

Pengaruh Model Pembelajaran Student Facilitator and Explaining Terhadap Hasil Belajar Siswa Pada Mata Pelajaran Sejarah Kelas X di SMA Negeri 3 Palembang

Sarinah, Nur Ahyani, Ahmad Zamhari 83-89

Pengaruh Model Pembelajaran Berbasis Masalah (PBM) Terhadap Hasil Belajar Siswa Pada Mata Pelajaran IPS Terpadu (Sejarah) Kelas VIII di SMP Negeri 2 Palembang

Neka Dapistri, Nur Ahyani, Ahmad Zamhari..... 90-95

Penerapan Media Pembelajaran Menggunakan Google Earth Dalam Materi Kondisi Masyarakat Indonesia Pada Masa Penjajahan Terhadap Hasil Belajar Siswa Pada Mata Pelajaran IPS Terpadu di SMP Quraniah Palembang

Tri Nur Ariani, Eva Dina Chairunisa, Ida Suryani $96-101$

Perkembangan Sosial Budaya Suku Jawa di Desa Kapasan Tegalrejo BK X Kecamatan Belitang Kabupaten Ogan Komering Ulu Timur Sebagai Sumber Pembelajaran Sejarah di SMA Muhammadiyah 2 Karang Tengah

Ratna Puspita Dewi, Sukardi, Mirza Fansyuri. $102-109$

Pengembangan E-Modul Pembelajaran Sejarah Tokoh-Tokoh Pembangunan Pacsa Kemerdekaan di Sumatera Selatan

Susi Susanti, Eva Dina Chairunisa 110-113

Peran Pendidikan Sejarah Dalam Membentuk Karakter Bangsa

Sukardi, Jeki Sepriady $114-117$

Sejarah Pengajaran Mantra Melayu di Tengah Perubahan Masyarakat Besemah Muhamad Idris, Eva Dina Chairunisa, Jeki Sepriady..... 118-127

Pengembangan Media Audio Visual Sejarah Kolonialisme Barat di Indonesia Materi Benteng Marlborough Bengkulu

Hamza Kurniawan. 128-135 
Kalpataru, Volume 6, Nomor 2, Desember 2020 (118-127)

\title{
SEJARAH PENGAJARAN MANTRA MELAYU DI TENGAH PERUBAHAN MASYARAKAT BESEMAH
}

\author{
Muhamad Idris \\ Dosen Program Pendidikan Sejarah FKIP Universitas PGRI Palembang \\ Email: muhamadidris_si@univpgri-palembang.ac.id \\ Eva Dina Chairunisa \\ Dosen Program Pendidikan Sejarah FKIP Universitas PGRI Palembang \\ Email: evadinachairunisa_si@univpgri-palembang.ac.id \\ Jeki Sepriady \\ Guru Sejarah di SMA Maitreyawira Palembang \\ Email: jeki.indonesia@gmail.com
}

\begin{abstract}
ABSTRAK
Mantra Melayu sedang mengalami ancaman tergerus modernisasi, tidak banyak masyarakat meneruskan tradisi melestarikan mantra sebagai bagian kehidupan keseharian di Sumatera Selatan. Permasalahan penelitian: bagaimana bentuk dan strategi pengajaran mantra Melayu di masyarakat Besemah Sumatera Selatan dalam arus modernisasi dan globalisasi. Tujuan penelitian: untuk mengetahui bentuk dan strategi pengajaran mantra Melayu di masyarakat Besemah Sumatera Selatan dalam arus modernisasi dan globalisasi. Manfaat penelitian tersedianya data dan informasi bentuk dan strategi pengajaran mantra Melayu di masyarakat Besemah Sumatera Selatan dalam arus modernisasi dan globalisasi. Metode penelitian yang digunakan deskriptif kualitatif. Hasil penelitian: mantra Melayu Besemah dikemas dalam bentuk rejung, tadut, guritan, tangis ayam, mantra sardundun. Pengajaran mantra secara tradisional dilakukan dengan metode lisan dari mulut ke mulut, namun diera keterbukaan dan upaya mengangkat budaya lokal di bidang pendidikan mantra diajarkan di sekolah-sekolah di kota Pagaralam dalam materi muatan lokal. Terobosan pengajaran ini dapat menyelamatkan mantra Besemah dari kepunahan.
\end{abstract}

Kata Kunci: Pengajaran, Mantra, Melayu.

\section{A. PENDAHULUAN}

Mantra Melayu merupakan kreativitas suku Melayu dalam mensikapi kebutuhan akan pengobatan, jaminan keamanan, kebutuhan keyakinan, kebutuhan akan kebutuhan hidup yang disesuaikan keadaan pada zamannya (Idris, 2017:105). Kondisi masyarakat Melayu Besemah yang hidup berdampingan dengan alam (Lapian, 2009:64), menghasilkan kreativitas sastra lisan yang menggambarkan pengetahuan tentang alam dan kearifan lokal masyarakat pada lingkungan.

Suku Melayu Besemah merupakan subetnik Melayu (Marsden, 2013:11) yang mendiami sebagian dataran, perbukitan dan pegunungan Sumatera Selatan (Zed, 2002:295). Wilayah administrasi Sumatera Selatan yang didiami sub etnik Melayu Besemah meliputi Kabupaten Lahat,
Kabupaten Muara Enim, Kabupaten Empat Lawang, Kota Pagaralam. Sub etnik Melayu Besemah memiliki kekayaan sastra lisan terlengkap di antara sub-etnik Melayu lainnya di Sumatera Selatan. Life cycle manusia Besemah mulai dari kelahiran sampai kematian diwarnai dengan sastra lisan.

Besemah sebagai sebuah sub kultur Melayu Sumatera Selatan mengalami dinamika perkembangan sosial budaya, ekonomi dan politik yang pesat setelah Indonesia merdeka. kebudayaan Besemah yang tersebar luas di Provinsi Sumatera Selatan menghadapi tantangan dalam pewarisan budaya dari satu generasi ke generasi berikutnya khususnya generasi muda di era milenial. Perkembangan teknologi dan dinamika budaya menjadi tantangan bagi pewarisan budaya. 
Permasalahan penelitian ini adalah: Bagaimana bentuk dan strategi pengajaran mantra Melayu di masyarakat Besemah Sumatera Selatan dalam arus modernisasi dan globalisasi.

Tujuan penelitian ini untuk mengetahui bentuk dan strategi pengajaran mantra Melayu di masyarakat Besemah Sumatera Selatan dalam arus modernisasi dan globalisasi.

Manfaat penelitian ini tersedianya data dan informasi pengajaran mantra Melayu masyarakat Besemah Sumatera Selatan dalam arus modernisasi dan globalisasi.

\section{B. METODE PENELITIAN}

Metode penelitian yang digunakan adalah deskriptif kualitatif, dengan anggapan bahwa metode ini dapat mengangkat fenomena permasalahan penelitian berupa bentuk dan strategi pengajaran mantra Melayu di masyarakat Besemah Sumatera Selatan dalam arus modernisasi dan globalisasi. Sumber data: wawancara dengan narasumber anggota masyarakat Besemah yang mengerti dan memiliki pengetahuan tentang pengajaran mantra Melayu masyarakat Besemah Sumatera Selatan; dokumen terkait tentang pengajaran mantra Melayu masyarakat Besemah Sumatera Selatan; observasi langsung di masyarakat Besemah tentang pengajaran mantra Melayu masyarakat Besemah Sumatera Selatan.

Teknik pengumpulan data: Observasi langsung pengajaran mantra Melayu di masyarakat Besemah di Kota Pagaralam sebagai pusat kebudayaan Besemah Sumatera Selatan; Pengumpulan dokumen di lokasi penelitian di Kota Pagaralam dengan pencatatan dokumen; Wawancara pada tokoh budaya, pewaris budaya dan masyarakat Besemah.

Teknik Cuplikan. Peneliti dalam melakukan kegiatan penelitian ini menggunakan teknik cuplikan purposive sampling, artinya sumber data dipilih melalui seleksi berdasarkan pertimbangan dan tujuan tertentu, yang dicuplik dalam penelitian ini adalah lokasi penelitian yang mewakili kelompok/ruang sebaran etnik Melayu Sumatera Selatan. Desa Lubuk Buntak, Desa
Tebat Gunung, Desa Bandar, Desa Tegur Wangi, Desa Tebing Tinggi, Desa Benua Keling, Desa Perahu Dipe mewakili Kota Pagaralam; Pemilihan lokasi dan informan dilakukan dengan pertimbangan: keberadaan data, kemudahan akses data dan kemudahan akses lokasi. Dalam purposive sampling peneliti memilih informannya berdasarkan posisi dengan akses tertentu yang dianggap memiliki informasi berdasarkan permasalahan secara mendalam (Soetopo, 2006:210), yang dicuplik dalam penelitian ini adalah warga masyarakat desa lokasi penelitian yang dijadikan sasaran penelitian terlebih dahulu dipilih berdasarkan karakteristiknya sesuai dengan kebutuhan dan kemantapan peneliti dalam perolehan data, teknik yang digunakan adalah internal sampling, teknik ini digunakan bukan untuk maksud atau kepentingan generalisasi.

Validitas Data. Validitas data sangat penting dalam proses pemaparan hasil penelitian, pembahasan dan penarikan simpulan. Dengan adanya validitas data, maka analisis dan penarikan simpulan telah dilandasi oleh kebenaran, karena berasal dari data yang telah teruji kebenarannya. Keabsahan atau validitas data merupakan faktor penting dalam penelitian, oleh sebab itulah perlu dilakukan pemeriksanaan data sebelum analisis dilakukan. Untuk menguji validitas data dalam penelitian ini dipergunakan teknik triangulasi. Teknik triangulasi adalah teknik pemeriksaan validitas data yang memanfaatkan sesuatu yang lain di luar data itu untuk keperluan pengecekan atau sebagai pembanding terhadap data itu. Terdapat empat teknik triangulasi, antara lain triangulasi data, triangulasi peneliti, triangulasi metode, dan triangulasi teori (Soetopo, 2006:92-102).

Teknik triangulasi yang dipergunakan peneliti dalam penelitian ini adalah teknik triangulasi data, dan triangulasi metode. Pada triangulasi data peneliti menguji kebenaran data dengan cara mengujinya dari data yang berbeda dari sumber yang berbeda. Pada triangulasi metode peneliti menguji kebenaran data dengan menggunakan metode pengumpulan data yang berbeda-beda, 
sehingga akan dapat disimpulkan data yang benar dan tepat untuk mengkonstruksi teori.

Teknik Analisis. Analisis yang dilakukan pada penelitian ini menggunakan analisis model interaktif terdiri atas tiga alur kegiatan yang terjadi secara bersamaan, yaitu reduksi data, penyajian data, dan penarikan kesimpulan (Soetopo, 2006:102). Reduksi data diartikan sebagai proses pemilihan, pemusatan perhatian pada penyederhanaan, pengabstrakan, dan transformasi data kasar yang muncul dari catatan-catatan tertulis di lapangan. Setelah data dikumpulkan dengan teknik wawancara, observasi, dan analisis dokumen, dilakukan reduksi data.

Setelah reduksi data, langkah berikutnya dalam analisis interaktif adalah peyajian data. Penyajian data yang paling sering digunakan dalam penelitian kualitatif adalah dalam bentuk teks naratif. Penyajian data dalam bentuk kualitatif dirancang guna menggabungkan informasi yang tersusun dalam suatu bentuk yang padu dan mudah diraih, sehingga peneliti dapat melihat apa yang sedang terjadi (Soetopo, 2006:102).

Kegiatan analisis yang ketiga adalah menarik kesimpulan dan verifikasi. Langkah awal dalam penarikan kesimpulan dan verifikasi dimulai dari penarikan kesimpulan sementara. Kemudin kesimpulan perlu diverifikasi agar cukup mantap dan dapat dipertanggung jawabkan. Oleh karena itu perlu dilakukan tinjauan ulang pada catatan di lapangan atau kesimpulan dapat ditinjau ulang sebagai makna yang muncul dari data yang harus diuji kebenarannya, kekokohan, dan kecocokannya. Namun demikian, jika kesimpulan masih belum mantap, maka peneliti dapat melakukan proses pengambilan data, sebagai landasan penarikan kesimpulan akhir.

\section{HASIL DAN PEMBAHASAN}

1. Hasil Penelitian

Dahulunya Sumatera Selatan merupakan bagian wilayah kekuasaan Kesultanan Palembang Darussalam, yang setelah jatuh ke tangan Belanda dan dihapuskannya sistem pemerintahan kesultanan, maka sistem politik di Sumatera Selatan digantikan dengan sistem residensi sejak tahun 1824. Keresidenan Palembang dengan batas wilayah dari laut melalui sungai Mesuji sampai Matawolu terus ditarik garis lengkok-lengkok sampai sumber mata air danau Seroja. Selanjutnya dalam garis berbelok-belok melalui puncak gunung Pungkau lewat Bukit Mandah dan melalui Pematang Tigaman sampai Bukit Pasagi (Supriyanto, 2013:44).

Wilayah Keresidenan Palembang meliputi beberapa afdeling. Afdeling dipimpin oleh asisten residen daerah afdeling dibagi menjadi beberapa onderafdeling yang dipimpin oleh seorang kontrolir. Wilayah pemerintahan kontrolir dibagi menjadi beberapa distrik yang dipimpin oleh seorang demang. Di wilayah keresidenan Palembang terdapat 15 distrik. Distrik dibagi menjadi beberapa onder distrik yang dipimpin oleh asisten demang (ada 40 orang asisten demang di Keresidenan Palembang). Kontrolir dalam menjalankan roda pemerintahan dibantu oleh personel mantri polisi, mantri pajak/belasting dan mantri kesehatan dengan pembagian wilayah Administrasi BB di Sumatera Selatan.

Tabel 1

Pembagian Wilayah Keresidenan Palembang

\begin{tabular}{|c|c|c|}
\hline $\begin{array}{c}\text { Keresidenan } \\
\text { Dipimpin } \\
\text { oleh } \\
\text { seorang } \\
\text { Residen }\end{array}$ & $\begin{array}{l}\text { Afdeling } \\
\text { Dipimpin oleh } \\
\text { seorang Asisten } \\
\text { Residen }\end{array}$ & $\begin{array}{l}\text { Onderafdeling } \\
\text { Dipimpin oleh } \\
\text { seorang } \\
\text { Kontrolir }\end{array}$ \\
\hline $\begin{array}{l}\text { Keresidenan } \\
\text { Palembang }\end{array}$ & $\begin{array}{l}\text { Daerah ibukota } \\
\text { Palembang } \\
\text { Afdeling } \\
\text { Palembang llir } \\
\text { dengan ibukota } \\
\text { Sekayu. } \\
\text { Afdeling } \\
\text { Palembang Ulu } \\
\text { (Palembangsche } \\
\text { Bovenlanden) } \\
\text { dengan ibukota } \\
\text { Lahat. } \\
\text { Afdeling Ogan Ulu } \\
\text { dan Komering } \\
\text { dengan ibukota } \\
\text { Baturaja. }\end{array}$ & $\begin{array}{l}\text { Musi llir; } \\
\text { Banyuasin dan } \\
\text { anah Koeboe; } \\
\text { Rawas; Ogan llir. } \\
\text { Lematang llir; } \\
\text { Lematang Ulu; } \\
\text { TanahPasemah; } \\
\text { TebingTinggi;Musi } \\
\text { Ulu. } \\
\\
\text { Komering } \\
\text { Ulu;Ogan } \\
\text { Ulu;Muara } \\
\text { Dua;Komering llir. }\end{array}$ \\
\hline
\end{tabular}


Sumber: Supriyanto, 2013:45

Meningkatknya kesadaran pemerintah Kolonial Belanda pada tanah jajahan di Keresidenan Palembang berdampak pada bidang pendidikan di daerah ini. Pada tahun 1864 pemerintah kolonial mendirikan Departemen Van Onderwijs, Eredienst en Nijverheid (Departemen Pengajaran, Ibadah dan Kerajinan). Pada tahun 1911 nama departemen tersebut berubah menjadi Departemen Van Onderwijs en Eredienst (Pengurus Besar Persatuan Guru Republik Indonesia, 2008:9).

Perkembangan politik di Eropa dan di tanah jajahan mendorong lahirnya politik Etika, yang bertujuan mengembangkan tanah jajahan untuk kepentingan penduduk bumiputera di bidang pendidikan, irigasi dan perpindahan penduduk. Perubahan kebijakan pemerintah kolonial Belanda di bidang pendidikan dengan memberi pengajaran rendah kepada bangsa bumiputera sesuai dengan kebutuhannya. Pemerintah kolonial Belanda memperbaiki pengajaran rendah bagi bumiputera. Pemerintah kolonial mengambil dua tindakan penting: memberi corak kebelandaan pada sekolah kelas 1 dan mendirikan sekolah desa. Pada tahun 1907 sekolah desa mulai didirikan di desa-desa atas biaya desa dan guru-guru diangkat oleh desa bukan pegawai negeri. Lama belajar 3 tahun pelajaran yang diajarkan adalah membaca, menulis dan berhitung (Pengurus Besar Persatuan Guru Republik Indonesia, 2008:12).

Pendidikan di Sumatera Selatan pada masa kolonial sampai tahun 1930 hanya diperuntukkan bagi para keturunan darah biru, seperti anak-anak residen, demang, asisten demang, depati dan pangeran serta pegawai pribumi yang telah teruji loyal kepada pemerintah penjajah. Mereka diduga sebagai pegawai kantor pemerintah penjajah, termasuk pribumi yang menjadi polisi dan tentara Belanda (Hasbullah, 1996:63). Dampak pendidikan kolonial di Sumatera Selatan adalah $12 \%$ penduduk Sumatera Selatan tidak lagi buta huruf dari 1.378 .510 (data sensus tahun 1930) (Hasbullah, 1996:19). Tingkat pendidikan yang rendah bagi orang Sumatera
Selatan di zaman Belanda sebagai akibat pembatasan yang terlalu ketat bagi rakyat biasa untuk mengakses ke lembaga pendidikan yang tersedia (Hasbullah, 1996:63).

Pantai Timur Sumatera Selatan memiliki daya tarik untuk disinggahi, pantai yang tenang dan damai di Barat selat Bangka, sungai yang lebar dan dalam dengan air tawar dan ikan yang melimpah. Muara sungai Musi merupakan tempat yang aman untuk berlindung ketika badai dari laut Cina Selatan menghantam kapal-kapal layar di selat Bangka. Tawaran kedamaian muara sungai Musi menjadi magnet pelaut-pelaut asing untuk melepas sauh di sungai Musi dan menetap di tepi sungai-sungai besar (Petters, 1997:38). Lingkungan hidup yang dekat dengan laut mendorong penduduk pesisir mengembangkan suatu cara hidup yang bersifat martim yang memanfaatkan laut dan pesisir bagi kelangsungan hidupnya (Lapian, 2009:77).

Migrasi orang-orang Melayu ke Sumatera Selatan telah berlangsung sejak ribuan tahun sebelum Masehi, jejak-jejak kuno ditemukan di dataran tinggi Besemah. Gelombang migrasi kedua yang disebut dengan Deutro Melayu pada 200-300 tahun senjata tajam untuk membuka hutan dan lahan memungkinkan orang bergerak secara lebih leluasa berpindah dari satu kawasan ke kawasan lainnya. Aktivitas migrasi ini memungkinkan terjadinya perkawinan campur dengan ras lain, mengadopsi identitas dan kebudayaan suku lain. Kelompok-kelompok migran Melayu ini kelak akan mengekspresikan budaya nenek moyang Melayu dari daerah asalnya dan mentransfomasikannya sesuai dengan kehidupan dunia yang senantiasa berubah (Mudra, 2008:29).

Sejarah Melayu di Sumatera Selatan memiliki hubungan erat dengan tokoh Sang Sapurba manusia setengah dewa dari India beserta pasukan yang besar datang ke Bukit Seguntang untuk mengumpulkan negeri taklukkan leluhurnya di Semenanjung Melayu dan Sumatera. Sang Sapurba bergelar Raja Natan Sang Sita Sangkala yang beragama Hindu. Penaklukan Palembang oleh Sang Sapurba melalui jalan damai, yaitu menikahkan putri Demang Lebar Daun dengan Sang 
Sapurba (Diradjo, 2014:58). Sang Sapurba kelak akan menurunkan raja-raja di negeri Melayu.

Pemukiman kota Sriwijaya sebagai cikal
bakal kota Palembang dan pusat perekonomian kuno sampai modern bukan terdiri atas rumah-rumah apung sungai, tapi yang dibangun sepanjang tepinya sepanjang sungai Musi di bagian Utara. Bangunan perumahan dibangun menempati bidang tanah kering yang disebut beting/tebing/tanggul sungai. Tebing sungai terbentuk dari peneplain yang ditempat ini bertemu dengan formasiformasi yang lebih baru (Coedes, 2014:210). Dunia Sumatera pada abad XVII dan XVIII perbedaan bahasa dan kebiasaan di dunia Hulu yang berkaitan dengan garis keturunan jelas menjadi basis organisasi sosial. Namanama yang diberikan pada kelompok keturunan ini beragam. Di Pasemah ada sumbai, di Komering ada buwei yang merupakan konsep keluarga besar yang berasal dari keturunan leluhur yang sama yang dikaitkan dengan daerah tertentu (Andaya, 2016:36). Penduduk yang mendiami mampu mengembangkan ekonomi lokal yang jaringan distribusinya sudah melampaui ruang kelompoknya. Sementara Hilir merupakan pusat aktivitas dagang. Hulu dicirikan dengan jumlah kampung-kampung sebagai titik perdagangan yang berkembang di persimpangan sungaisungai penting (Andaya, 2016:39).

Jaringan komunikasi dan lalulintas, tukar menukar informasi dan bahan dengan frekuensi tinggi mampu mendorong manusia setempat menciptakan kebudayaan di permukimannya. Jaringan komunikasi dibangun melalui sungai-sungai yang merayap di kaki bukit, lembah dan gunung melintasi dataran rendah menuju pesisir. Angkutan air kala itu lebih efektif dan efisien dibandingkan angkutan melalui darat (Hanafiah, 1995:6). Dusun atau kampung adalah sekelompok rumah yang didiami oleh manusia berdasarkan ikatan-ikatan kekerabatan dan sosial tertentu. Pembangunan dusun dan kampung selalu berada di pinggir sungai/tebing sungai/beting atau di lebak atau rawa. Air merupakan sarana dan kebutuhan pokok dalam kehidupan masyarakat Melayu. Permukiman dibangun diatas tempat yang tinggi dengan beberapa pertimbangan penting seperti keamanan dan kenyamanan terutama dari serangan musuh, binatang buas, binatang melata serta serangga yang mengganggu. Untuk mencapai inti rumah penghuninya harus melalui tangga yang cukup terjal. Perkampungan biasanya dikelilingi oleh tanaman buah-buahan, kelapa, pinang, lahan yang dibersihkan untuk ditanami padi (Marsden, 2013:60).

Pendidikan masa kolonial yang tidak berpihak pada penduduk asli Indonesia, berdampak pada berkembangnya institusi pendidikan Islam dan pendidikan lokal lainnya. Peluang berkembang bahkan tidak terusiknya institusi pendidikan formal dan informal lokal oleh kebijakan kolonial Belanda berdampak pada kelangsungan sastra lisan dan budaya lokal lainnya.

\section{Mantra Melayu Besemah}

Mantra sebagai bagian dari tradisi lisan Besemah yang sarat nilai religus magis bertahan ditengah arus perubahan dari masa ke masa. Salah satu contoh mantra Melayu Besemah adalah mantra Sardundun. Mantra Sardundun adalah mantra yang diucapkan ketika prosesi pernikahan dalam budaya Melayu Besemah. Sardundun bermakna burung Cawi/sawi berduyun-duyun. Dalam hikayat diceritakan Syair Kawin Sardundun menggambarkan kontribusi Islam dalam metafora ungkapan adat Besemah. Syair Kawin Sardudun atau merupakan kependekan dari Burung sawi Bardundun, Burungsawi bardundun disingkat Sardundun. Syair Sardundun ini merupakan bacaan taklid dalam upacara pernikahan adat Besemah. Syair yang menceritakan tentang perlunya pernikahan untuk mencegah perzinahan antara laki-laki dengan perempuan. Nilai Islam pada syair ini terdapat pada baris pertama dan kedua bait kedua: Seramekalaikum langit, Seramekalaikum bumi merupakan pengucapan tidak sempurna dari Asalamualaikum. Ketika Islam sudah mulai banyak dan secara luas difahami oleh warga Besemah, maka secara perlahan pembacaan taklid adat ini digantikan dengan yang lebih Islami berupa bacaan akad nikah Islam. 
Kawin Sardundun. Burungsawi Bardundun, Burungsawi bardundun disingkat Sardundun. Tradisi Sardundun dikisahkan ketika puyang Atung Bungsu berkelana untuk mencari jodohnya Beteri Kenantan Buwih. Pertemuan di atas kapal Puyang Atung Bungsu dengan Beteri Kenantan Buwih disaksikan oleh burung sawi. Burung sawi yang hinggap di tiang layar adalah bukan burung sawi biasa, karena mampu bercakap-cakap dan menasehati kedua insan tersebut. Nasihat burung sawi tersebut disebut dengan sawi bardundun dan disingkat dengan sardundun. Sardundun merupakan lafas akad nikah adat Besemah Tuwe. Setelah Atung Bungsu, nama Atung Bungsu dan Beteri Kenantan Buwih diganti dengan nama pengantin. Ungkapan Njadikah jagad Besemah diganti dengan ngembangkah juray. Pembacaan akad nikah dipimpin oleh seorang dukun.

Potongan bacaan kawin adat Besemah atau kain sardundun sebagai berikut:

\section{Kawin Sardundun}

Seramekalaikum langit

seramekalaikum bumi

seghat langit aram temaram

Aruskah Tuwan kan nameku?

Seghat bumi aram temaram

Arus melaikat nameku?

Masteridin si kembang nunur Inderecaye kembang mamur Kembang luk bunge semerunak Kembang luk bunge semerulum Kembang luk caye sinaran bulan Kembang luk caye mateari Kembang pembarap nggah pembukur Kembang di kidaw nggah di kanan

Mbaktulah pule kembange

Atung Bungsu nggah Beteri Kenantan Buwih njadikah jagat Besemah

Mantra Kawin Sardundun sebagai mantra Melayu Besemah merupakan mantra sakral yang mengandung nilai religio magis. Mantra Kawin Sardundun sebagai mantra ucap hanya diajarkan menjelang upacara akad nikah dalam budaya Melayu Besemah. Pewarisan mantra dilakukan dalam lingkup terbatas dan ruang tertentu. Hanya orang tua-tua tertentu yang ditunjuk untuk meneruskan mantra ini pada generasi berikutnya yang terpilih.

Mantra Jampi Pughu Kayu (Rengasan)

Syarate kemiling (kemiri) 7 biji diambil dalamnya

Bismillahirohmanirohim

Hut Allah 3x

Gajah kepite bejalan malam

Ketemu nga anak kampang (111)

Ngape kaba disini aku disikse li manusie

Getah putat jadi santak baung (112)

Getah kemang jadi santak kalang (113)

Ulat puagh abis bise

Allah mengetahui

Allah mengetahui

Minyak kemirinya dioleskan ke pughu (koreng) (Iskandar, 1986:481).

\section{Bentuk dan Strategi Pengajaran Mantra Melayu Besemah}

Agen atau Orang tua-tualjeme tue dalam kasus pengajaran mantra dalam budaya Melayu Besemah memiliki peran besar dalam kehidupan sosial pada bidang tertentu dalam masyarakat desa. Melalui keahliannnya mereka mampu memberikan pertolongan dan perlindungan pada masyarakat desa. Pada kasus jeme tue di Besemah, karena pengaruh dan keahliannnya diminta pertolongan dalam berbagai aspek budaya desa. Peran mereka sangat besar memberikan sugesti, jimat dan nasehat pada warga desa dan pimpinan mereka. Pada umumnya peran mereka diminta secara diam-diam, biasanya dilakukan pada malam hari, karena datang ke dukun/jeme tue sering jadi bahan pembicaraan warga desa. Kemampuan jeme tue dalam mempengaruhi warga sangat besar, sehingga kepala desa menempatkannya pada tempat duduk yang tidak jauh darinya pada saat rapat-rapat desa

Pada kasus pengajaran mantra dalam bentuk rejung, peran aktor dalam mempengaruhi masa lebih banyak dengan memanfaatkan media cerdas, seperti tampil di acara-acara sekolah yang memasukkan kesenian lokal dalam kurikulum muatan lokal seperti di Sekolah Menengah Atas di Kota Pagaralam. Perejung menularkan kemampuan 
berejungnya kepada generasi muda Besemah. Penutur mantra lisan rejung atau tadut biasanya disebut seniman. Seniman lebih menunjukkan pengaruhnya pada skala luas dari pada jeme tue yang hanya pada lingkup desa. Pengaruh kesenian mampu melintas ruang dan waktu, yang tidak melihat unsur etnisitas semata.

Pada kasus jeme tue, mereka secara rutin memantau kasus yang mereka tangani melalui media komunikasi dan perantara yang mereka percayai seperti anggota keluarga pasiennya. Pada kasus tingkat desa biasanya jeme tue akan memonitoring melalui kaki tangan kepala desa yang sebelumnya menjadi perantara tindakan kepala desa dengan jeme tue. Pada kasus pesenjang dan perejung peran guru sekolah dan pegawai dinas kebudayaan dan pengurus PKK kota sangat penting dalam perbaikan tindakan di masyarakat. Tindakan pemantauan akan berhenti pada kasus pengobatan apabila tidak ada lagi keluhan dari keluarga pasien yang sakit. Pada kasus perejung dan pesenjang tindakan pemantauan memakan waktu yang panjang, seperti kegiatan perejung yang melatih kesenian rejung ibu-ibu darma wanita Kota Pagaralam, proses latihan sekaligus pemantauan dilakukan berbulan-bulan sampai ibu-ibu darma wanita mampu berejung dengan baik di depan publik Kota Pagaralam.

Proses pewarisan mantra melalui kegiatan belajar. Pembelajaran mantra jeme tue kepada gurunya dengan melalui tahapan: pertama, murid menghadap guru mengutarakan niatnya untuk belajar dan menjadi murid pada gurunya. Guru menggunakan mata batinnya untuk melihat kekuatan niat dan keseriusan calon muridnya. Guru akan menguji kesungguhan hati calon muridnya dengan mengajukan beberapa ujian, seperti ujian mental dan fisik; kedua, guru akan mengajukan ulang pertanyaan pada calon muridnya tentang kesungguhan hatinya; ketiga, murid diminta untuk melakukan bersuci sebelum menyambut mantra dan pada beberapa mantra sipenyambut harus berpuasa terlebih dahulu. Penyambut diminta berpuasa dengan niat tertentu; keempat, nyambut mantra merupakan inti dari upacara ini. Kegiatan nyambut mantra dilakukan pada malam hari, setelah sipenyambut berbuka puasa, kalau si penyambut shalat biasanya dilakukan setelah shalat Isya. Guru akan duduk berhadapan di depan muridnya. Guru akan meminta muridnya untuk mengingat mantra yang akan diucapkan dan tidak boleh diulang, harus sekali ucap diingat dan hafal. Setelah murid merasa siap dan mampu, pembacaan mantra oleh guru dimulai dan akan diikuti dengan pelafasan oleh muridnya; kelima, penyambutan akan dinilai berhasil apabila murid mampu menghafalkan mantra/jampi dalam satu kali ucap. Apabila gagal, maka proses pengulangan ritual dari awal dilakukan oleh si murid yang gagal; keenam, sang guru akan berpesan pada muridnya agar menjaga kerahasiaan mantra/jampi dan memanfaatkannnya untuk hal yang baik-baik saja.

Motif jeme tue mengacu pada keinginankeinginan yang mendorongnya akan tetapi, motivasi tidak dibatasi langsung oleh kesinambungan tindakan-tindakan seperti halnya monitoring refleksif atau rasionalisasinya. Motivasi jeme tue, mengacu pada potensi tindakan, bukan pada cara tindakan dilakukan secara terus-menerus oleh agen (Giddens, 2016:23). Motif-motif jeme tue memiliki hubungan langsung dengan tindakan hanya dalam keadaan-keadaan yang relatif tidak lazim, situasi terputus dari rutinitas yang memberikan keseluruhan rencana atau program. Terlepas dari hal tersebut di atas perilaku keseharian jeme tue tidak didasarkan pada motivasi intrinsik dan ekstrinsik mereka dalam melakukan tindakan penanganan bidang keahliannya. Jeme tue memiliki gagasan tentang kesadaran praktis, untuk memperbaiki citra dirinya sebagai orang yang menjalankan keahliannnya dibidangnya.

Pola aktivitas yang teratur dikenal dengan istilah struktur sosial disusun oleh para agen: jeme tue dengan memproduksi sejumlah kondisi yang memungkinkan menyusun aktivitas. Proses sosial membentuk para aktor menjadi kunci ahli dari sejumlah harapan dan praktik melalui praktek pengobatan/perdukunan yang dipadukan dengan kesadaran bersama bahwa mantra hanya media namun berminta hanya kepada Allah SWT. Mantra/jampi 
merupakan media pengobatan (Idris, 2019:127) untuk menanamkan sugesti pada pasiennya, maka aktor jeme tue memberikan harapan pada pasien dengan praktek pengobatan yang dilakukan.

Jeme tue setelah melalui proses pembelajaran kepada pasien atau muridnya akan menginternalisasikan nilai dan aturan. Tindakan dilakukan sesuai dengan aturanaturan yang dibuat, aturan diproduksi secara berulang. Selanjutnya jeme tue akan melakukan aturan-aturan dilembagakan oleh masyarakat dan anggota kelompok sehingga menjadi aturan bersama yang disepakati (Idris, 2019:128).

Jeme tue merupakan bagian dari sebuah skema kebudayaan, dimana ada masyarakat yang membutuhkan jasa jeme tue, kebudayaan dan pemerintah desa yang memberi ruang jeme tue terlibat peran pada struktur kebudayaan desa melalui ilmu pengobatan. Reproduksi struktur dapat terjadi apabila tercipta peluang.

Struktur sebagai seperangkat aturan dan sumber daya atau seperangkat relasi transformasi yang terorganisasi sebagai kelengkapan dari sistem sosial, diciptakan secara sadar oleh jeme tue. Tanpa aturan dan sumberdaya peraturan maka ketika aktor tersebut tidak akan mampu bermain peran walau unsur intrinsik dan ekstrinsik sebagai pendorong ia miliki. Struktur mampu menopang peran mereka untuk menciptakan relasi yang direproduksi untuk terus menjaga hubungan atau relasi antara ketiga aktor tersebut dengan masyarakat baik yang membutuhkan dan yang tidak membutuhkan. Melalui sistem yang dibangun oleh para aktor dan masyarakat setidaknya mampu mempertahankan peran aktor dalam bermain perannya di masyarakat. Kondisi-kondisi sekitar mendukung pengulangan struktur yang dibangun atas dasar kesadaran kolektif. Kapan hal tersebut akan hilang apabila masyarakat sudah tidak membutuhkan lagi peran aktor dalam komunitasnya.

Seseorang dapat menjadi tokoh/aktor setelah melalui proses atau jalan yang panjang. Aktor dan masyarakat ibaratkan dua sisi mata uang yang tidak dapat dipisahkan, sehingga aktor jeme tue dituntut memiliki kemampuan introspeksi dan mawas diri dari para agen di dalam dan sebagai pembentuk, duree aktivitas sosial sehari-hari yang akan dipengaruhi pengetahuannya. Dalam menjalankan perannya jeme tue dituntut harus mengembangkan keterampilannya untuk menghadapi arus perubahan. Jeme tue akan mengembangkan penggunaan media pengobatan yang dituntut kreativitasnya dalam memenuhi kebutuhan masyarakat akan karya yang kreatif dan inovatif. Tanpa kemampuan ini mereka akan tertelan arus kebudayaan di masyarakat yang semakin gencar merusak sendi-sendi budaya lokal. Pada jeme tue proses penyaringan informasi ini melibatkan usaha reflektif para aktor dengan posisi strategis untuk mengatur keseluruhan kondisi reproduksi sistem, dengan tujuan menjaga agar segala sesuatu tetap seperti sediakala dan untuk mengubah segala sesuatu berkenaan dengan pekerjaan atau profesi mereka sebagai pakar pengobatan lokal.

Secara sadar jeme tue merupakan bagian integral dari sebuah satu kesatuan masyarakat baik di tingkat terkecil maupun di kota. Secara sadar para aktor tersebut di atas menjaga integrasi mereka sebagai bagian dari masyarakat sepanjang hidup mereka di tengah masyarakat.

Jeme tue sudah memahami pentingnya mantra dalam kehidupan sehari-hari, dengan pensosialisasian secara tidak langsung dengan memanfaatkan orang yang berhasil ditolongnya setidaknya menjadi corong pemasaran ke tengah publik desa. Pengakuan atau testimoni warga yang berhasil menjadi alat legitimasi publik bahwa jeme tue yang mereka percayai memang ampuh dan paten. Masyarakat yang telah memiliki norma menempatkan dunia pengobatan sebagai bagian terintegrasi dalam kehidupan masyarakat desa. Akan tetapi pelanggaran yang dilakukan oleh jeme tue akan dihadapkan pada norma yang telah disepakati bersama oleh penduduk desa seperti pengucilan, sampai pada penutupan dan pengusiran jeme tue dari desa.

Jeme tue sebagai bagian dari masyarakat desa dengan strata sosial yang berbeda dengan masyarakat biasa, memiliki 
kekuasaan yang disepakati oleh masyarakat desa. Batas-batas kekuasaan disepakati bersama antara jeme tue dengan pemimpin dan masyarakat desa. Dampaknya jeme tue mendapatkan fasilitas-fasilitas khusus yang diberikan oleh warga desa, seperti mendapatkan udangan sebagai tamu penting dalam acara-acara warga desa, mendapatkan perlindungan dari warga desa apabila mendapatkan ancaman.

Pengetahuan yang digunakan jeme tue dalam produksi dan reproduksi interaksi sama dengan bekal pengetahuan yang membuat mereka mampu menciptakan cerita, mengemukakan alasan. Jeme tue secara rutin melibatkan bagian-bagian temporal dan spasial perjumpaan-perjumpaan dalam proses penciptaan makna. Komunikasi sebagai unsur umum interaksi, merupakan konsep yang mencakup dibandingkan dengan isi komunikasi.

Jeme tue sebagai anggota masyarakat secara rutin menjaga komunikasi dengan warga masyarakat. Komunikasi jeme tue dengan warga desa dilakukan sangat natural, tanpa settingan, sehingga masyarakat menerima jeme tue apa adanya sebagai bagian anggota masyarakat biasa, akan tetapi memiliki hak-hak tertentu di tingkat desa. Pada kasus orang sebagai warga desa lainnya yang tidak mendapatkan keistimewaan dalam berkomunikasi. Akan tetapi aktor masih tetap menjaga hubungan baik dengan anggota masyarakat lainnya.

\section{Pembahasan}

Penyajian mantra Melayu Besemah dalam keseharian sangat variatif tergantung bentuk sastra lisan dan tulisan yang hidup di dalam masyarakat itu sendiri. Penyajian mantra atau jampi terkadang menggunakan media benda hidup atau benda mati, seperti air putih, daun sirih, lidah biawak dan sebagainya. Penggunaan media tersebut seperti halnya musik dalam penyajian rejung semakin menjadikan pembacaan puisi berupa mantra/jampi atau rejung menjadi hidup. Pada kasus pembacaan mantra/jampi terkadang penggunaan gerak menjadikan puisi tersebut semakin menimbulkan kesan mistis aktor dalam pandangan masyarakat yang melihatnya. Pengajaran sastra lisan oleh aktor kepada yang murid menerima ilmu berupa mantra/jampi didasarkan pada niat baik, kepercayaan, kemampuan dan hubungan baik antara aktor atau agen dengan muridnya atau aktor/agen muda. Tanda didasari pada hal tersebut di atasmaka sangat mustahil penurunan mantra/jampi dapat dilakukan. Sebuah kesadaran berperan penting dalam penyajian jampi/mantra yang mengandung metafora atau tidak, akan tetapi terkadang dalam beberapa kejadian sang dukun sebagai aktor/agen tanpa sadar membacakannya.

Sebuah kesadaran yang dilakukan melalui dunia pendidikan nampaknya merupakan sebuah upaya ampuh untuk pelestarian metafora yang terkandung dalam sastra lisan dan sastra tulisan. Peran masyarakat sangat penting serta peran pemerintah sangat dinantikan sebagaimana dicontohkan oleh pemerintah Kota Palembang dan Provinsi Sumatera Selatan dalam pelestarian mantra. Namun, masih banyak data mantra yang menanti untuk diselamatkan. Sebagaimana penelitian ini yang baru menemukan ratusan mantra dan masih ada ribuan mantra dalam kebudayaan Melayu Sumatera Selatan yang belum terdata, belum tercatat yang masih tersimpan dalam sastra lisan dan sastra tulisan Melayu Sumatera Selatan. Sebuah kajian besar dari berbagai sudut ilmu dan dengan beragam pendekatan nampaknya yang akan menyelamatkan mantra Melayu Sumatera Selatan dari kehilangan dan kemusnahan. Kelak hasil kajian-kajian tersebut dapat dimanfaatkan dalam pembangunan Sumatera Selatan khususnya dan dunia Melayu umumnya yang sangat beragam serta sangat kompleks yang hidup di tengah multi kultural Indonesia dan dunia internasional. Kajian mantra ini diharapkan bukan menjadi kajian akhir namun dapat menjadi pijakan awal dalam membangun sebuah kajian kebudayaan sastra lisan dan sastra tulisan Melayu Sumatera Selatan yang sangat kaya.

\section{SIMPULAN}

Mantra Melayu Besemah dikemas dalam bentuk rejung, tadut, guritan, tangis ayam, 
Mantra Sardundun. Pengajaran mantra secara tradisional dilakukan dengan metode lisan dari mulut ke mulut, namun diera keterbukaan dan upaya mengangkat budaya lokal di bidang pendidikan mantra diajarkan di sekolahsekolah di Kota Pagaralam dalam materi muatan lokal. Terobosan pengajaran ini dapat menyelamatkan mantra Besemah dari kepunahan.

Pemanfaatan mantra dalam pembangunan di Sumatera Selatan adalah sebuah keharusan dan keniscayaan mengingat perlunya kearifan lokal yang berbasis pada kebudayaan setempat sebagai pondasi yang kokoh dalam pembangunan masyarakat Melayu Sumatera Selatan yang prural.

Pembangunan sebuah pendidikan yang secara sadar memasukan kebudayaan dan kearifan lokal Melayu Sumatera Selatan merupakan wahana yang ampuh untuk membangun kesadaran kolektif masyarakat Sumatera Selatan sebagai masyarakat yang majemuk di tengah masyarakat Indonesia yang beragam dan kaya budaya.

\section{DAFTAR PUSTAKA}

Andaya, Barbara Watson. 2016. Hidup Bersaudara Sumatera Tenggara Pada Abad XVII dan XVIII. Yogyakarta: Ombak.

Coedes, George, dkk. 2014. Kedatuan Sriwijaya. Jakarta: Komunitas Bambu.

Diradjo, Ibrahim Dt. Sanggoeno. 2014. Tambo Alam Minangkabau Tatanan Adat Warisan Nenek Moyang Orang Minang. Bukit Tinggi: Kristal Multimedia.

Giddens, Anthony. 2016. Teori Strukturasi Dasar-dasar Pembentukan Struktur Sosial Masyarakat. Yogyakarta: Pustaka Pelajar.

Hanafiah, Djohan. 1995. Melayu-Jawa: Citra Budaya dan Sejarah Palembang. Jakarta: PT Raja Grafindo Persada.
Hasbullah, Jousairi. 1996. Mamang dan Belanda (Goresan Wajah Sosial Ekonomi dan Kependudukan Sumatera Selatan Zaman Kolonial dan Refleksinya Pada Hari Ini). Palembang: Unsri.

Idris, Muhamad dan Jeki Sepriady. "Sastra Tutur Desa Lebak Bering Kabupaten Ogan Komering llir Sebagai Sumber Pembelajaran Sejarah". Dalam Kalpataru. Volume 3, Nomor 1, Juli 2017. (104-111).

Idris, Muhamad. "Metafora Dalam Kebudayaan Islam Melayu Sumatera Selatan". Dalam Kalpataru. Volume 5, Nomor 2, Desember 2019. (126-140).

Iskandar, Teuku. 1986. Kamus Dewan. Kuala Lumpur: Dewan Bahasa dan Pustaka.

Lapian, Adrian B. 2009. Orang Laut, Bajak Laut, Raja Laut, Sejarah Kawasan Laut Sulawesi Abad XIX. Depok: Komunitas Bambu.

Marsden, William. 2013. Sejarah Sumatera. Jakarta: Komunitas Bambu.

Mudra, Mahyudin Al. 2008. Redefinisi Melayu Upaya Menjembatani Perbedaan Konsep Kemelayuan Bangsa Serumpun. Yogyakarta: Balai Kajian dan Pengembangan Budaya Melayu.

Peeters, Jeroen. 1997. Kaum Tuo-Kaum Mudo Perubahan Relegius Palembang 18211942. Jakarta: INIS.

Pengurus Besar Persatuan Guru Republik Indonesia. 2008. Seratus Tahun Perjuangan Guru Indonesia. Jakarta: Departemen Pendidikan Nasional.

Soetopo, H.B. 2006. Metodologi Penelitian Kualitatif, Dasar Teori dan Terapannya Dalam Penelitian. Surakarta: Universitas Sebelas Maret. 
Supriyanto. 2013. Pelayaran dan Perdagangan di Pelabuhan Palembang 1824-1964. Yogyakarta: Ombak.

Zed, Mestika. 2002. "Ekonomi Dualistis Palembang Pada Periode Kolonial Akhir". Dalam Fondasi Ekonomi Indonesia. J. Thomas Lindblad (Ed). Yogyakarta: Pusat Studi Asia Tenggara. 


\section{KETENTUAN PENULISAN ARTIKEL JURNAL KALPATARU}

1. Naskah berbahasa Indonesia yang disempurnakan bertemakan kesejarah yang meliputi hasil penelitian sejarah, pengajaran sejarah dan penelitian kebudayaan.

2. Naskah harus asli dan belum pernah dimuat dalam media lain. Naskah dapat berupa hasil penelitian/artikel kajian konseptual yang ditulis oleh perorangan dan atau kelompok.

3. Naskah ditulis dengan cara-cara yang sesuai dengan ketentuan penulisan artikel ilmiah menggunakan bahasa Indonesia yang baku, berupa ketikan, beserta soft file dalam CD-RW atau dengan mengirimkan email pada redaksi jurnal Kalpataru dengan alamat jurnalkalpatarusejarah@gmail.com, spasi tunggal, jenis huruf arial narrow ukuran 12, dengan panjang naskah antara 8-15 halaman pada kertas A4.

4. Artikel hasil penelitian memuat:

JUDUL

Nama Penulis

Abstrak

A. PENDAHULUAN

B. METODE PENELITIAN

C. HASIL DAN PEMBAHASAN

D. SIMPULAN

DAFTAR PUSTAKA
: XXX (HURUF KAPITAL)

: (disertai jabatan, institusi, dan email)

: (Bahasa Indonesia yang memuat 100-200 kata diikuti kata kunci, dengan jenis huruf arrial narrow dan ukuran huruf 11 serta dicetak miring).

: (memuat latar belakang masalah, tinjauan pustaka secara ringkas, masalah penelitian, dan tujuan penelitian).

5. Artikel Kajian Konseptual memuat:

JUDUL

Nama Penulis

Abstrak

PENDAHULUAN

Sub Judul

Simpulan

DAFTAR PUSTAKA
: (berisi simpulan).

: (berisi pustaka yang dirujuk dalam uraian naskah).

6. Referensi sumber dalam teks artikel ditulis dengan menggunakan side note, contoh (Jalaludin, 1991:79); sementara penulisan daftar pustaka disusun dengan ketentuan. Nama pengarang. Tahun terbit. Judul (dicetak miring). Kota terbit: Nama Penerbit. Contoh: Koentjaraningrat. 2010. Manusia dan Kebudayaan di Indonesia. Jakarta: Djambatan. Daftar pustaka hanya memuat pustaka/sumber yang dirujuk dalam uraian dan disusun menurut abjad tanpa nomor urut.

7. Naskah yang dimuat akan disunting kembali oleh redaksi tanpa mengubah isinya.

8. Naskah yang ditolak (tidak bisa dimuat) akan dikirim kembali ke penulis dengan pemberitahuan tertulis dari redaksi atau melalui email.

9. Penulis yang naskahnya dimuat akan mendapat 1 (satu) majalah nomor yang bersangkutan.

10.Kontak person: Muhamad Idris (081271498618); Eva Dina Chairunisa (082281267851); Jeki Sepriady (085269261780). 